\title{
In-Situ and Ex-Situ status of the Javan Gibbon and the role of zoos in conservation of the species
}

\author{
Vincent Nijman \\ Zoological Museum, University of Amsterdam, PO Box 94766, 1090 GT Amsterdam, The Netherlands, E-mail: \\ nijman@science.uva.nl
}

Key words: captive populations, conservation, Indonesia, PHVA, population management

\begin{abstract}
The Javan gibbon Hylobates moloch is confined to the last remnants of rainforest on the island of Java, Indonesia. As of 2002, the species has been recorded in 29 forest areas, and the wild population is conservatively estimated at $4100-4500$ individuals. Over $95 \%$ of the gibbons are in populations of $>100$ individuals, and the four largest areas support populations of $>500$ individuals each. In 2003, 56 Javan gibbons were maintained at eight Indonesian zoos, 15 at four Indonesian wildlife rescue centres, with five potential breeding pairs. There is no evidence that the species has bred successfully in captivity in Indonesia. Outside the range country, 48 Javan gibbons were maintained at ten institutions in nine countries, with six breeding pairs. The total ex-situ population is some 120 individuals, the majority of which is wild-caught. At present most initiatives relating to the conservation of the Javan gibbon have targeted small isolated forest areas and the ex-situ population, whereas in-situ protection of the largest populations in the wild has been largely ignored. Significant populations are currently found in unprotected forests. The large captive population of Javan gibbons within Indonesia allows, with improved co-operation, to set up an integrated captive-breeding programme. This should, not be seen, however, as a means to improve the conservation status of the wild Javan gibbons, which needs to be achieved through protection of remaining habitat, but could be used for improving the prevailing low levels of conservation awareness in Java.
\end{abstract}

\section{Contents}

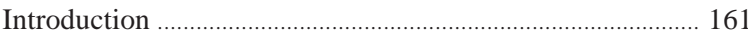

Methods ……………………………………………………........ 162

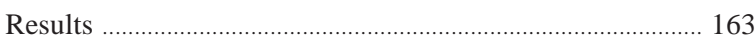

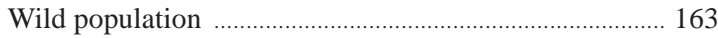

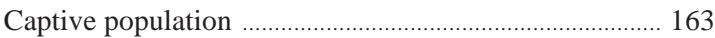

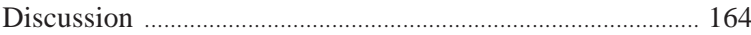

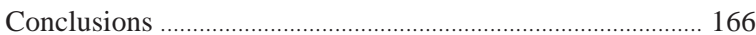

Acknowledgements ..................................................................... 167

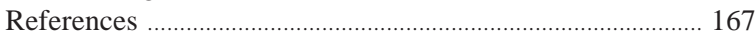

\section{Introduction}

The Javan gibbon Hylobates moloch (also known as silvery gibbon) is confined to patches of undisturbed lowland and lower montane rainforest below 1600$1800 \mathrm{~m}$ asl on the western part of island of Java, Indonesia. Java is densely populated with about 120 million people at an average population density of $>900$ people $\mathrm{km}^{-2}$. Although once fully covered in forest, it is now largely cultivated and forest remains as scattered isolated pockets. Hence, populations of Javan gibbons are highly fragmented and are threatened mainly by loss and degradation of habitat. Alongside 19 other primate taxa, the Javan gibbon is listed as Critically Endangered by IUCN (note however that this assessment was made in 2001 and new information on the conservation status of many taxa has emerged, for Southeast Asia see e.g. Geissmann et al. 2004 and Nijman 2004b). The Javan gibbon is furthermore included on Appendix I of CITES (Convention on International Trade in Endangered Species of Wild Fauna and Flora) (which prohibits all international trade of the species, its parts and derivatives, among contracting parties), and it was among the first species to become protected by Indonesian law in 1925. In recent years, little research has been conducted on the Javan gibbon, and that has been mostly on behavioural aspects (e.g. Dallmann and Geissmann 2001ab, Geismann et al. 2005, Geissmann and Nijman 2006, Malone et al. 2004, Rinaldi 2003; but see Djanibudiman et al. 2004).

Gates (1998) provided an overview of the in-situ and ex-situ status of the Javan gibbon. Most of his data from the wild population was derived from a 
Population and Habitat Viability Analysis (PHVA) workshop that was held by the Conservation Breeding Specialist Group of the IUCN (Supriatna et al., 1994). He summarised that the observed population of about 400 individuals was found in 21 habitat fragments, 18 of which contained fewer than 30 animals, and none of these areas supported populations of more than 100 individuals. A Vortex analysis revealed that a 100 individuals is the approximate threshold level below which populations run a $>1 \%$ chance of extinction over a 100 year time period (Supriatna et al., 1994). Gates (1998) also provided an update on the ex-situ status of the Javan gibbon as of 1996 and concluded that 14 Javan gibbons were maintained in four Indonesian zoos and 27 Javan gibbons in six institutions outside Indonesia. He then discussed some of the priorities for gibbon conservation and some of the interventions that he deemed necessary to manage the population. In short these priorities were: 1 . The periodic transfer of 2-3 individuals between wild population fragments, as part of a regional management strategy, and protection of small populations from illegal capture of animals. 2. Increased protection of Mt Halimun National Park and restoration of degraded areas within the national park in order to allow for a significant natural increase in the gibbon population in the future. 3. Establishment of ten breeding pairs in Indonesian zoos.

I recently completed a study on the conservation status of Javan gibbons in the wild (Nijman, 2004a), and as part of an assessment of the trade in primates I compiled data on the number of captive Javan gibbons in Indonesia (Nijman, 2005ab, unpublished data). The results from these studies differ substantially from those presented by Gates (1998) and, as almost ten years have passed since Gates' review, an updated assessment is presented of the in-situ and ex-situ status of the Javan gibbon. Furthermore, I will present an alternative view on prioritising conservation and management strategies, and discuss the role zoos can play in this.

\section{Methods}

I assessed the status of the wild Javan gibbon population by surveying forest areas in 1994-2002 (Nijman, 1995, 2001, 2004a; Geissmann and Nijman 2006). The status of the captive Javan gibbon population was assessed in 2003-2004 by visiting 14 zoological gardens and 11 wildlife rescue centres in western Indonesia. The origin of the gibbons was requested from the directors and members of staff. Data on confiscation of illegally-held gibbons and subsequent prosecution of owners and traders were requested from the Indonesian forestry department. Data on the captive Javan gibbon population outside Indonesia were retrieved from Thomas Geissmann's Gibbon Network (www.gibbons.de, last updated November 2003), with additional data from Cocks (2001), and corroborated through searches on the internet.

Table 1. Ex-situ and in-situ population of the Javan gibbon Hylobates moloch, presenting a summary of Gates’ (1998) review ${ }^{1}$ and the present assessment ${ }^{2}$. Median refers to the median number of individuals per population.

\begin{tabular}{|c|c|c|c|c|}
\hline & \multicolumn{2}{|c|}{ Gates (1994-1996) } & \multicolumn{2}{|c|}{ Nijman (2002-2003) } \\
\hline & $\begin{array}{l}\text { Individuals } \\
\text { (populations) }\end{array}$ & Median & $\begin{array}{l}\text { Individuals } \\
\text { (populations) }\end{array}$ & Median \\
\hline Large populations $^{3}$ & $250(5)$ & 36 & $3400-3800(7)$ & 560 \\
\hline Small populations & $150(16)$ & 10 & $700-720(22)$ & 22 \\
\hline Total in situ & $400(21)$ & 13 & $4100-4500(29)$ & 50 \\
\hline Wildlife rescue centres & $0(0)$ & 0 & $15(4)$ & 3 \\
\hline Zoos in Indonesia & $14(4)$ & 3.5 & $56(8)$ & 8 \\
\hline Zoos outside range country & $27(6)$ & 2.5 & $48(10)$ & 2.5 \\
\hline Total ex situ & $41(10)$ & 3 & $119(22)$ & 3 \\
\hline Total in-situ and ex situ & 441 & & $4119-4619$ & \\
\hline
\end{tabular}

${ }^{1}$ Additional data retrieved from Supriatna et al. (1994) and Cocks (2001)

2 Methods and number of institutions included in the assessments differ, precluding conclusions on possible changes between 19941996 and 2002-2003.

${ }^{3}$ Large populations are the top-quarter of populations. 


\section{Results}

\section{Wild population}

The Javan gibbon is present in 29 forest areas in western Java (Fig. 1). The total population is conservatively estimated at 4100 to 4500 gibbons (Table 1). Although there are a relatively large number of forest fragments with small numbers of gibbons, $>95 \%$ of the gibbons are in 11 discrete populations of a hundred individuals or more.

The four largest populations are located in $\mathrm{Mt}$ Halimun (>800 gibbons), Mt Simpang, Mts Dieng and Ujung Kulon (c. 500-600 gibbons each). The first and the last areas mentioned are gazetted as national parks and have some basic management facilities in place. Mt Simpang is a strict nature reserve without any facilities or wardens, with protection being restricted to sign posts demarcating the borders, whereas Mts. Dieng is largely unprotected. Half of the 15 largest populations, representing about a third of the total wild population of Javan gibbons, are found in forest areas outside the protected area network.

\section{Captive population}

Eight out of 14 zoological gardens surveyed had one or more Javan gibbons on display, with a combined total of 56 individuals. Many of these were held either in solitary confinement or in large (nonfamily) groups, often comprising of more than one

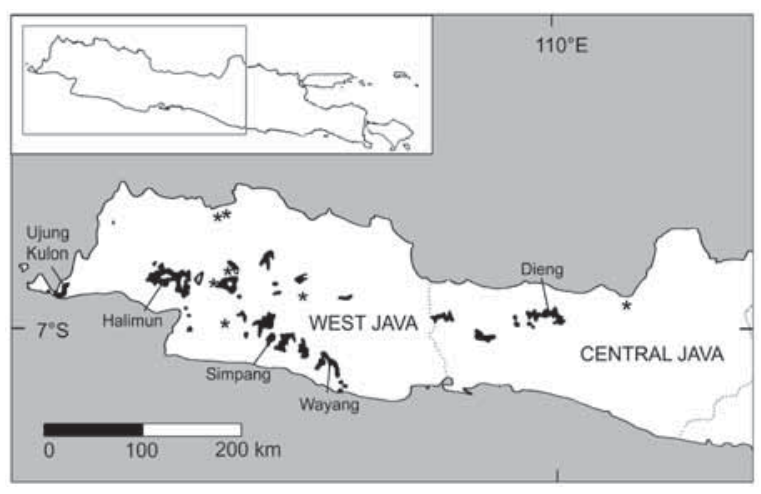

Fig. 1. Global distribution of the Javan gibbon Hylobates moloch on the western part of the island of Java, Indonesia, indicating locations mentioned in the text. The asterisks refer to the locations of zoos and wildlife rescue centres that keep the species. species of gibbon. In most zoos housing conditions were extremely poor, especially when set against western standards, with the exception of the recently opened Schmutzer Primate Centre in Jakarta and, at least for Javan gibbons, Bali Zoo Park near Denpasar and Taman Safari Indonesia in Cisarua. These three zoos were also the only that maintained at least part of their Javan gibbons in pairs, in such conditions that they could potentially produce offspring. Concerning the origin of the Javan gibbons in these zoos, from 12 this was either unknown or I was unable to trace it, 15 were transferred from other zoos within Indonesia, 24 were donated by the public, and three were confiscated by wildlife conservation authorities (though none of the owners prosecuted). All but two were wild-caught, and for the two that were allegedly captive-bred, insufficient reliable information was available to assess whether this was indeed the case. To the best of my knowledge Javan gibbons have not reproduced successfully in any of these Indonesian zoos.

In four wildlife rescue centres there were 15 Javan gibbons, seven of which were confiscated (again, none of the owners were prosecuted) and eight were donated by the public. Despite best efforts, housing conditions in most of the wildlife rescue centres, although often considerably better than in zoos, are not up to western standards, and most individuals were kept solitary. With the exception of four Javan gibbons donated to the Javan Gibbon Rescue and Rehabilitation Centre at Bodogol in 2003, at least at the moment, none of these gibbons are intended to participate in a breeding programme. As such, as of 2004 there are at least 70 Javan gibbons in Indonesian institutions, of which there is a maximum of five potential breeding pairs, and no definite proof of successful breeding.

After 1978 (when Indonesia acceded to the CITES) at least nine wild-caught Javan gibbons were exported from Indonesia to foreign zoos. Outside Indonesia there are 48 Javan gibbons at ten institutions in nine countries. Three of these institutions have successfully bred the species, with some six breeding pairs. At least $60 \%$ of the Javan gibbons outside Indonesia are captive-bred. As such, the global ex-situ population of the Javan gibbon falls just short of 120 individuals at 22 institutions in ten countries; the majority of these are wild-caught and do not form part of a breeding programme. 


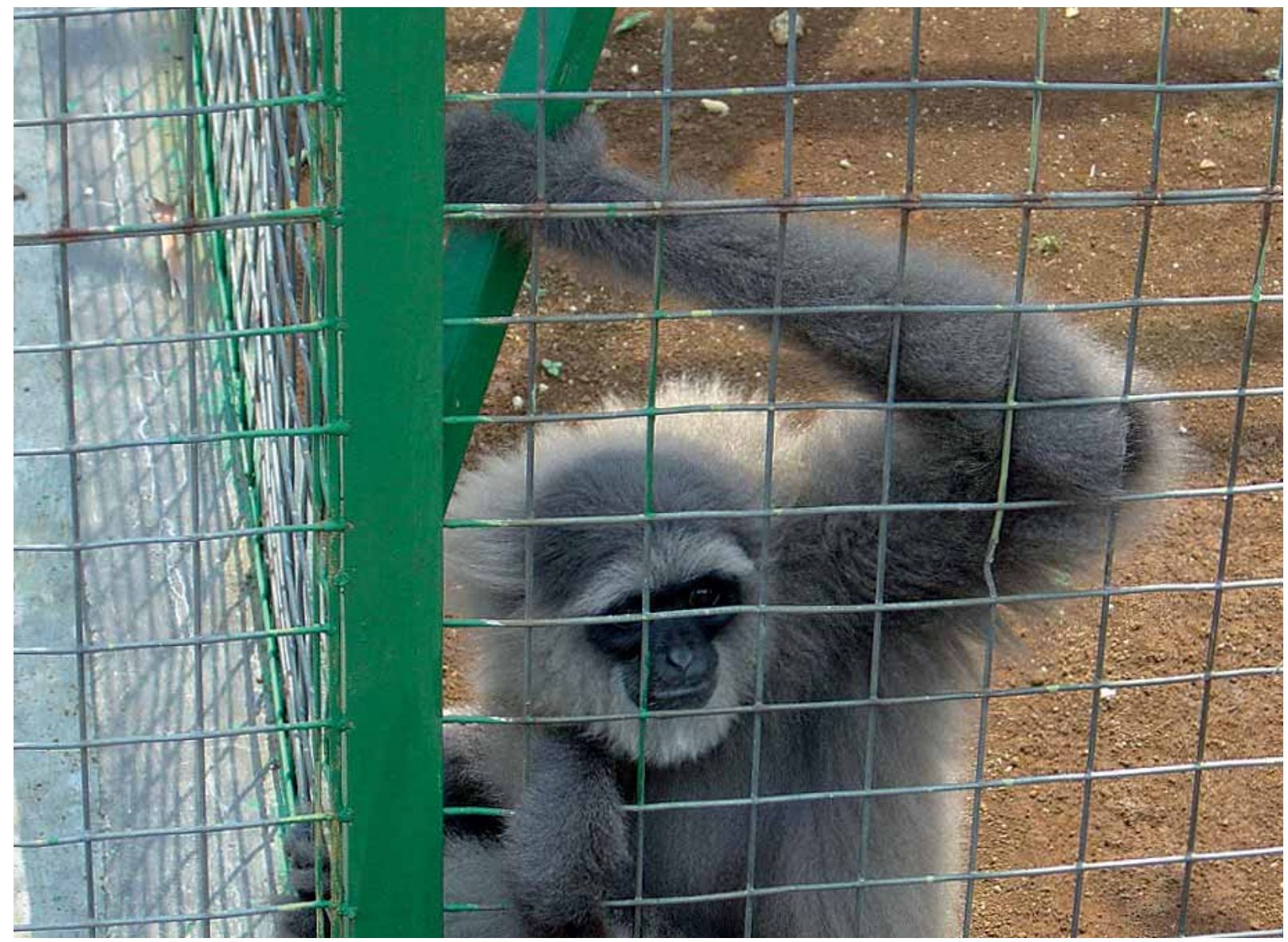

Fig. 2. Javan gibbon Hylobates moloch at the Javan Gibbon Rescue and Rehabilitation Centre at Bodogol, West Java, Indonesia in October 2004 (Photo: E.M. Burgess).

\section{Discussion}

The wild Javan gibbon population is severely fragmented with many small populations. By and large these fragments are separated from other forests by several kilometer-wide gaps of non-forest, cultivated, land. Natural expansion of the population is not an option as most if not all of the forest areas (including those that are legally protected) are facing encroachment into the remaining forest to some extent. There are no indications of populations being far below the carrying capacity of the forest (i.e. there are no 'emptied forests' within the range of the species). Gates (1998) suggested that Mt Halimun National Park had the greatest potential for natural expansion of Javan gibbon population. This would be valid if, indeed, less than a hundred individuals would be present in the $400 \mathrm{~km}^{2}$ large reserve, as implied by Gates $(1996,1998)$. However, numerous studies have been conducted on the gibbons in $\mathrm{Mt}$ Halimun National Park, some with the specific aim to estimate the total population size of the reserve. Kappeler (1981) estimated the population in Mt Halimun National Park at 600-1800 gibbons, Kool (1992) at 850-1320 gibbons, Asquith et al. (1995) at 870 gibbons, Sugarjito and Sinaga (1997) at 864936 gibbons, Rinaldi (2003) at 456-1149 gibbons, and Djanubudiman et al. (2004) at 2905 gibbons. All these estimates from one forest area (out of 29 inhabited by Javan gibbons) are larger than the total world population presented by Gates (1998). Although Mt Halimun National Park is of major importance to the protection of the Javan gibbon, unfortunately some of the most valuable lowland forests are situated outside the boundaries of the reserve, are discontinuous, and are, therefore, not as secure 
as it may seem (Whitten et al., 1996). Furthermore, encroachment is threatening the integrity of the park, both from the central enclave (expansion of the tea estate), as well as from the park's periphery. Conservation (and research) efforts are concentrated in the eastern part of the park, and, although a management plan has been drawn, active protection of the forest receives little attention.

The largest unprotected population of Javan gibbons is found Mts. Dieng, representing the species' easternmost population with a population of $>500$ individuals (Nijman, 1995; Nijman and van Balen, 1998; Geissmann and Nijman 2006). As noted by Gates (1998) Mts Dieng may be as significant for the Javan gibbon as the Mt Halimun National Park; it was however not included in the PHVA on which Gates' (1998) review was based. The forests on Mts. Dieng receive no form of protection, even though proposals for increased protection have been submitted to the authorities. The forest has suffered significantly during and following the economic crisis that hit Indonesia in 1997-1998, and the period of social and political turmoil that followed, with large areas being affected by illegal small-scale logging. No data are available as to what extent the forests in Mts. Dieng have suffered, nor what the effects are on the population of Javan gibbons, but losses must have been significant.

At the PHVA workshop (Supriatna et al., 1994) a substantial proportion of time was spent forcing participants to estimate numbers they had no ability or authority to estimate (Asquith, 2001). The resulting estimate of 400 individuals as the total population of Javan gibbons made during the PHVA workshop was largely based on the number of gibbons that the participants of this workshop had themselves observed. Thus, the population of the $400-\mathrm{km}^{2} \mathrm{Mt}$ Halimun National Park, for which various studies have indicated that the population numbers over 800 gibbons (see references listed above), was estimated at 53 individuals as those attending the workshop had observed a mere 16 groups. The method employed at the PHVA has been criticised (Asquith, 1995, 2001; Nijman, 2004a) and even the senior author of these PHVA proceedings has revised these numbers upward (Supriatna and Wahyono, 2000).

In formulating a conservation strategy for the Javan gibbon, Supriatna (2001) argued that "While conservation programs might focus primarily on the core populations...smaller populations on different sites should not be undervalued since they may function as critical stepping-stones that allow gene exchange and colonization to take place. Establishing habitat corridors among those several small and large protected areas should become the first priority while also establishing a wild sanctuary that brings together individuals from different populations". Likewise, Gates (1998) and others (Andayani et al., 2001; Ellis, 1996/1997; Supriatna et al., 1994; Supriatna and Manullang, 1999; Malone et al. 2004) have stressed and reiterated the importance of protection of small fragmented populations, and the need for metapopulation management through some form of genetic supplementation, including plans to capture young gibbons preparing to leave their families and take them to other areas (Derr, 2002).

These interventions, and the focus on small populations, were justified by making reference to the small population size (i.e. the purported 400 individuals), that is extremely fragmented, with essentially no viable population (>100 individuals) remaining. If this situation were to be true it is easy to see the importance of the captive population as almost a quarter of the world population of Javan gibbons would indeed be in captivity (Table 1).

With many more gibbons remaining in the wild than presumed by some, the question arises also what is the conservation value of the ex-situ Javan gibbon population and how it can contribute to conservation of wild Javan gibbons? At present, within Indonesia, there is a relatively large captive population of Javan gibbons, in zoological gardens, wildlife rescue centres, and, almost invariably illegally, in private hands. All are directly derived from the wild and, with a few notable exceptions, are currently kept in appalling conditions. A number of initiatives have recently started to improve the lives of these captive animals either by improving conditions in zoos, or even by rehabilitation and release in isolated forest areas without resident gibbons. This may be a way to solve the dilemma of what to do with large numbers of long-lived gibbons held in captivity, but should not be confused with being a conservation strategy for the species. Initiatives to improve the lives of captive Javan gibbons and programmes that enables the Indonesian conservation authorities to house confiscated gibbons properly are to be applauded, but will contribute little to 
increase the survival chances of gibbons in the remaining forests on Java. If these initiatives would be made an integral part of a larger scheme covering law-enforcement and public-awareness campaigns, they could benefit the wild population by enhanced protection. Current offenders of wildlife laws, however, are rarely prosecuted (despite intensive searches I am not aware of any conviction of someone that illegally killed, caught, kept or traded a Javan gibbon). The current system, where the public can 'donate' their pet gibbon to zoos, wildlife rescue centres and rehabilitation programmes, has created too easy a solution for private owners to get rid of their adult gibbon. This has led to a situation where one can renew illegal wildlife (e.g. get a younger individual and dispose of on older one) and has created a loophole for malevolent zoos. Despite the current laissez-faire situation, there are still opportunities for an increased co-operation between Indonesian zoos, wildlife rescue centres and the forestry department with the aim of setting up a co-ordinated captive-management programme within Indonesia. The number of captive gibbons is sufficiently large, and, with the help for foreign zoos and international NGOs husbandry conditions within Indonesia can be improved, with the ultimate outcome of the much desired integrated captive-breeding programme (Gates, 1998; cf. Ware, 2001).

For the real protection of the Javan gibbons, however, we have to focus fully our attention on the remaining forest habitat in which Javan gibbons occur. Gates (1998), and others with him, targeted the relatively small number of individuals that are found in a large number of small populations (including the ex-situ population). Here I would like to argue that the best strategy is to focus on the large number of individuals found in a small number of larger forest blocks. As indeed pointed out by Asquith (2001), the most cost-effective and meaningful strategy for bettering the conservation status of the Javan gibbon is improvement of the protection of the largest remaining forest area which contains significant numbers of Javan gibbons. Secondly, it will be of vital importance to stimulate and continue efforts of including unprotected gibbon populations into the protectedarea network (cf. Birkett, 2005). The areas most urgently in need of improved protection are Mts Dieng and Mt Wayang, but in effect all large populations could do with an increase in active field protection.
This increased protection is best achieved by a pragmatic approach involving the different sections of the Ministry of Forestry (Directorate General for Forest Conservation and Nature Protection and Perum Perhutani), local authorities (including those from nearby communities) and local non-governmental organizations (NGOs). The lead in this is best taken by a small, dedicated group that lobbies at the local and regional levels as to get various stakeholders and the local authorities on board. Alongside, campaigning and education to inform on the plight of the Javan gibbon and its habitat should target the local, regional and national level (cf. Wahyono et al., 2000). With their expertise in raising awareness, national zoos, as well as wildlife rescue centres, can take a lead in this. A way to prevent encroachment and illicit logging in selected forest areas is to set up a system where patrol teams involving local community representatives, local NGOs, the forestry department, and police (operating in mixed teams so as to prevent internal collusion) for prolonged periods of time. Institutional and financial support for this could be made available by international donors, including foreign zoos.

\section{Conclusions}

1. The wild Javan gibbon population consists of some 4100-4500 individuals, and although fragmented in 29 subpopulations, $>95 \%$ of the individuals are in populations of $>100$ individuals. Significant populations are found in forest areas not included in the protected area network, facing an unnecessary uncertain future.

2. As of 2004, the captive population of Javan gibbon consists of 119 individuals in 22 institutions in ten countries; the majority of these are wildcaught and do not form part of a breeding programme. The ex-situ population in Indonesia (71 gibbons in 12 institutions) is large enough to initiate a co-ordinated captive-breeding programme.

3. The improvement of the status of the wild Javan gibbon is best achieved through increased protection of remaining habitat, and the captive breeding programme could be used to improve prevailing low levels of conservation awareness on Java. 


\section{Acknowledgements}

I would like to thank the Indonesian Institute of Sciences (LIPI) and the Directorate General for Forest Conservation and Nature Protection (PHKA) for allowing me to conduct my research. Financial support for my studies were provided by WWF Germany (through TRAFFIC Southeast Asia), Netherlands Foundation for International Nature Protection, Society for the Advancement of Research in the Tropics, M. de Beukelaar Foundation and J.C. van der Hucht Fund. E.M. Burgess (Massey University, Albany NZ), R. Wirth (ZGAP, München) and G.M. Fredriksson (University of Amsterdam) are thanked for information and support. I thank the reviewers for their helpful comments on the manuscript.

\section{References}

Andayani N, Morales JC, Forstner MRJ, Supriatna J, Melnick DJ. 2001. Genetic variability in mtDNA of the silvery gibbon: implications for the conservation of a critically endangered species. Conserv. Biol. 15: 770-775.

Asquith NM. 1995. Javan gibbon conservation: why habitat protection is crucial. Trop. Biodiv. 3: 63-65.

Asquith NM. 2001. Misdirections in conservation biology. Conserv. Biol. 15: 345-352.

Asquith NM, Martarinza, Sinaga RM. 1995. The Javan gibbon (Hylobates moloch): status and conservation recommendations. Trop. Biodiv. 3: 1-14.

Birkett L. 2005. Conservation strategies for the Javan gibbon (Hylobates moloch): with a focus on reintroduction and captive care. Unpubl. B.A. thesis, Department of Human Sciences, University of Oxford, UK.

Cocks L. 2001. International studbook for Javan gibbons (Hylobates moloch). Perth: Perth Zoological Gardens.

Dallmann R, Geissmann T. 2001a. Different levels of variability in the female song of wild silvery gibbons (Hylobates moloch). Behaviour 138: 629-648.

Dallmann R, Geissmann T. 2001b. Individuality in the female songs of wild Silvery Gibbons (Hylobates moloch) on Java, Indonesia. Contrib. Zool. 70: 41-50.

Derr M. 2002. Acrobatic ape in Java is in high-wire survival struggle. New York Times, February 5: 5.

Djanubudiman G, Pambudi JAA, Raharjo B, Hidayat M, Wibisono F. 2004. Laporan awal: Populasi, distribusi dan konservasi owa jawa (Hylobates moloch Audebert, 1798). Depok: YABSI and PSBK.

Ellis S. 1996/1997. Primate conservation and the IUCN/SSC Conservation Breeding Specialist Group: tools, models and processes. Primate Conserv. 17: 41-45.

Gates R. 1996. In situ conservation in Java - Perth Zoo's Silvery gibbon project. Intern. Zoo News 43: 327-329.
Gates R. 1998. In situ and ex situ conservation of the Silvery or Moloch gibbon Hylobates moloch. Intern. Zoo Yearb. 36: 81-84.

Geissmann T, Groves CP, Roos C. 2004. The Tenasserim lutung, Trachypithecus barbei (Blyth, 1847) (Primates: Cercopithecidae): description of a live specimen, and a reassessment of phylogenetic affinities, taxonomic history and distribution. Contrib. Zool. 73: 271-282.

Geissmann T, Nijman V. 2006. Calling in wild silvery gibbons (Hylobates moloch) in Java (Indonesia): Behavior, phylogeny, and conservation. Am J Primatol 68: 1-19.

Geissmann T, Bohlen-Eyring S, Heuck A. 2005. The male song of the Javan silverey gibbon (Hylobates moloch). Contrib. Zool. 74: 1-26.

Kappeler M. 1981. The Javan silvery gibbon (Hylobates lar moloch). (dissertation). Basel: Basel University.

Kappeler M. 1984. The gibbon in Java. In Preuschoft H, Chivers DJ, Brockelman WY, Creel N, editors. The Lesser Apes: evolutionary and behavioral biology. Edinburgh: Edinburgh University Press. p 19-31.

Kool KM. 1992. The status of endangered primates in Gunung Halimun reserve, Indonesia. Oryx 26: 29-33.

Malone N, Oktavinalis H. 2006. The socio-ecology of the silvery gibbon (Hylobates moloch) in the Cagar Alam Leuweung Sancang (CALS), West Java, Indonesia. Am. J. Phys. Anthropol. 42: 124.

Malone, NM, Pakpahan, H., Oktavinalis, H. 2004. Behavioural and ecological responses of Silvery gibbons (Hylobates moloch) to severe habitat degradation in the Cagar Alam Leuweung Sancang, West Java, Indonesia. Folia Primatol. 75: 115.

Nijman V. 1995. Remarks on the occurrence of gibbons in Central Java. Primate Conserv. 16: 66-67.

Nijman V. 2001. Forest (and) primates. Conservation and ecology of the endemic primates of Java and Borneo. TropenbosKalimantan Series 5. Wageningen: Tropenbos.

Nijman V. 2004a. Conservation of the Javan gibbon Hylobates moloch: population estimates, local extinctions, and conservation priorities. Raffles Bull. Zool. 52: 271-280.

Nijman V. 2004b. Effects of habitat disturbance and hunting on the density and biomass of the endemic Hose's leaf monkey Presbytis hosei (Thomas, 1889) (Mammalia: Primates: Cercopithecidae) in east Borneo. Contr. Zool. 73: 283-291.

Nijman V. 2005a. In full swing. An assessment of the trade in orangutans and gibbons on Java and Bali, Indonesia. Kuala Lumpur: TRAFFIC South-east Asia.

Nijman V. 2005b. Hanging in the balance. An assessment of the trade in orangutans and gibbons on Kalimantan, Indonesia. Kuala Lumpur: TRAFFIC South-east Asia.

Nijman V, van Balen S. 1998. A faunal survey of the Dieng mountains, Central Java, Indonesia: status and distribution of endemic primate taxa. Oryx 32: 145-156.

Rinaldi D. 2003. The study of Javan gibbon (Hylobates moloch Audebert) in Gunung Halimun National Park (distribution, population and behavior). In: Sakagushi N, ed. Research and conservation of biodiversity in Indonesia Vol. XI: Research on endangered species in Gunung Halimun National Park. Bogor: JIKA Biodiversity Conservation Project. p 30-48. 
Sugarjito J, Sinaga MH. 1999. Conservation status and population distribution of primates in Gunung Halimun National Park, West Java, Indonesia. In: Supriatna J, Manullang BO, eds. Proceeding of the international workshop on Javan gibbon (Hylobates moloch): rescue and rehabilitation. Jakarta: Conservation International Indonesia Program and Center for Biodiversity and Conservation Studies. p 6-12

Supriatna J. 2001. Current status and conservation strategy for Javan gibbon (Hylobates moloch) [Abstract]. P. 361 in: The Apes: Challenges for the $21^{\text {st }}$ century. Chicago: Brookfield Zoo.

Supriatna J, Manullang BO. 1999. Proceeding of the international workshop on Javan gibbon (Hylobates moloch): rescue and rehabilitation. Jakarta: Conservation International Indonesia Program and Center for Biodiversity and Conservation Studies.

Supriatna J, Tilson R, Gurmaya KJ, Manansang J, Wardojo W, Sriyanto A, Teare A, Castle K, Seal U. 1994. Javan gibbon and Javan langur: Population and habitat viability analysis report. Apple Valley, Minnesota: IUCN/SSC Conservation Breeding Specialist Group.
Supriatna J, Wahyono EH. 2000. Panduan lapangan primata Indonesia. Jakarta: Yayasan Obor Indonesia.

Wahyono EH, Sarilani NP, Ario A, Hutabarat H. 2000. Owa jawa (Hylobates moloch) sebagai daya tarik alam pendidikan konservasi. In: Yuda P, Salasia SIO, eds. Konservasi satwa primata: Tinjuan ekologi, sosial ekonomi dan medis dalam pengembangan ilmu pengetahuan dan teknologi. Yogyakarta, Gadjah Madah University. p 224-231.

Ware D. 2001. Gibbon rehabilitation and reintroduction: the problems along the road before use as a viable conservation tool. Pp 259-261 in: The Apes: Challenges for the $21^{\text {st }}$ century. Brookfield, USA: Chicago Zoological Society.

Whitten AJ, Soeriaatmadja RE, Afiff SA. 1996. The ecology of Java and Bali, the ecology of Indonesia series Vol II. Singapore: Periplus Editions.

Received: 9 May 2006

Accepted: 6 October 2006 